transfer factor, so that this strain, too, acquires on advantage in an environment in which the now character is needed for survival.

The transfer factor may be lost at some stage during the spread of an $R$-factor". The resulting organism retains the $R$-determinant which it can transmit to its lineal descendants only and which appears to be stable. Superficially, these organisms resemble drug-resistant mutants.

The transfer factors have a very widc host range. For example, they may be transmitted, together with the resistance determinants they carry, and presumably with other genetic determinants, to the following 'genera' of Gram-negative bacilli: Escherichia, Salmonella, Shigella, Proteus, Serratia, Pasteurella, Vibrio, and others. The full range of characters for which the transfor factors can act as vectors is not yet known, but it may prove to be extensive. The same transfer factor will transfer different charanters and the samo charactcr may be carried by different transfor factors.

The observations presented here suggest that the transfer factors may have more evolutionary importance in the bacterial systems in which they operate than has been hitherto imagined. Although devoid of the property of extra-cellular invasion, thoy have an immense ecological advantage because of their high communicability and wide host range. They can carry genetic determinants which may ultimately prove to be numerous. By this mechanism those doterminants may be widely distributed among different species or genera of Gram-negative bacilli, so that determinants in a given strain may have originated in a bacterial species normally regarded as belonging to a different genus. Whothor such genetic determinants can become integratod into the chromosomes of their new carrier cells is not yet known. If they can, it may be supposed that, once integrated, they aro indistinguishable in origin from other chromosomal characters and are Ioralizable on the bacterial linkage map. But even if they remain cytoplasmic in location they are stable cellular enmponents. Whether they enter the chromosome or remain cytoplasmic, therefore, they become part of the genome of their host cells.

Extensive exchange of characters between the Gramnegative bacilli need not be expected to lead to genetic uniformity in the different host species, except in relation to the individual characters concerned. On the contrary, it may encourage diversification, because in each case the effect of a now character has to be assessed through its summation with the bacterial genome as it existed up to the time of acquisition of the new character, and the ultimate effect of the now modified genome on the ecology of the recipient organism.

I thought it worth while to voice these speculations because if the long-term activity of transfer factors has influenced bacterial evolution, the evolutionary time-scale may have been telescoped into a shorter span than that envisaged purely in terms of the selection of mutants with survival advantages. The obvious question that arises is whether efficient mechanisms of genetic distribution such as those I have discussed exist only in the Enterobacteriaceae, or indeed whether they are limited to the bacteria. If they operate in other forms of life, some $r \Theta$-thinking may be called for in relation to evolution in other fields of biology.

Enteric Referonce Laboratory,

Public Health Laboratory Service,

Colindale Avenue, London, N.W.9.

${ }^{1}$ Hayes, W., J. Gen. Microbiol., 8, 72 (1953).

${ }^{2}$ Frédéricq, P., C.R. Soc. Biol. (Paris), 148, 399 (1954).

${ }^{3}$ Ochiai, K., Yamanaka, T., Kimura, K., and Sawada, O. (in Japanese), Nippon Iji Shimpo, 1861, 34 (1959) (quoted by Watanabe, see ref. 5).

${ }^{4}$ A kiba, T., Koyama, K., Ishiki, Y., Kimura, S., and Jukushimo, T., Japan. kiba, T., Koyama, K, Ishiki,
Jicrobiol., 4, $219(1960)$.

${ }^{5}$ Watanabe, T., Bact. Rev., 27, 87 (1963).

6 Anderson, E. S., and T.wig, M. J., Nalure, 208, 813 (1965)

7 Anderson, E. S., Nature, 208, 1016 (1965).

${ }^{3}$ Anderson, E. S., Brit. Med. J., 11, 1289 (1965).

\section{Correlation of Temperature-dependent Water Properties and the Growth of Bacteria}

IN rocent years there has been some evidence to suggest that biological activity may bo affected by water struc$\operatorname{ture}^{1,8}$. The premise of the above work was that water undergoes subtle structural changes at specific temperatures $^{3,4}$ and, if biological growth is affected by water structuro, growth should be affected at these temperatures. Since the effect of water structure on biological activity has not been substantiated, an investigntion of the effect of temperature on bacterial growth was undertaken.

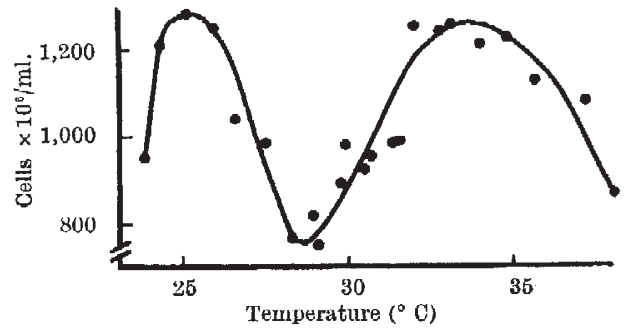

Fig. 1. Number of cells of Streplococcus fuecalis at different temperatures

Using a polytemperature thermostat, similar to that described elscwhere", cultures of Streptococeus faecalis were simultaneously grown in broth culture at nincteen temperaturos ranging from $20^{\circ}$ to $40^{\circ} \mathrm{C}$. The culture tubes were prepared and placed in the incubator at least $8 \mathrm{~h}$ prior to inoculation so that temperature equilibrium within the medium would be reached. Inoculum consisted of a loop of cells from a 24-h broth culture of the organism. (Krowth was stopped after a 20 -h incubation period by placing the culture tubes in $50^{\circ} \mathrm{C}$ water. Bacterial multiplication was determined by direct cell counts in a haemocytorneter.

Typical results are shown in Fig. 1. Near $30^{\circ} \mathrm{C}$ there is a marked reduction in number of cells. The temperature of reduced cell multiplication corresponds to a temperature at which a change in water structure takes place. Theso data support the postulate that biological activity is affected by water structure. This work is being extended to other bacteria and temperatures.

\section{B. Davey}

RAYMOND J. MULLER

Department of Soil Science,

North Carolina State, Raleigh, N.C.

1 Mitchell, H. K., and Houlahan, Mary B., Amer, J. Bot., 33, 31 (1046).

"Oppenheimer, C. II., and Drost-Hansen, W., J. Bact., 80, 21 (1960).

${ }^{3}$ Gupta, S. R., Hills, G. J., and Ives, D. J. G., Disc. Faraday Soc., 24, 147 (1957).

4 Lavergne, M., and Drost-Hansen, W., Naturwise., 48, 511 (1956).

\section{Staphylococcus aureus Strains in the '52, $52 A, 80,81$ Complex'}

THe phage-typing pattern of a strain of Staphylococcus aureus is believed to be determined by two factors: the 'basic' sensitivity of the strain to lysis by the typing phages, modified by interference exerted by the prophage or prophages it carries. The specificity of this interferoneo may bo narrow, and prevent lysis only by the phage carried by the strain and by closely relatied phages, or it may be very broad. Sornetimes a single prophage will block the sensitivity to a number of apparently unrelated phages and have a profound effect on tho phage-typing pattern 1,2 .

Under natural conditions the typing pattern of a strain may bo changed by lysogenization, and this may load to difficulties in the interpretation of long-term epidemio. logical investigations. It has proved possible, however, 